\title{
Świat wartości swoich i obcych w Krzyżakach Henryka Sienkiewicza
}

Zdaniem badaczy i krytyków twórczości Henryka Sienkiewicza najważniejszą przyczyną powstania Krzyżaków - ostatniej (dokończonej) powieści historycznej pisarza była chęć ,krzepienia zwątlałych serc Polaków”. Nasilone w drugiej połowie XIX wieku działania germanizacyjne i rusyfikacyjne zaborców sprawiły, że w umyśle ,autora Trylogii dojrzała decyzja darowania społeczeństwu polskiemu dzieła, które dodałoby sił do przetrwania ucisku i może - doczekania innych czasów"2. Pokazanie wyższości naszej polskiej, słowiańskiej kultury, naszego świata wartości, naszych postaw w opozycji do wyraźnie negatywnego obrazu realiów świata krzyżackiego, germańskiego stało się najważniejszym elementem rzeczywistości wykreowanej w powieści. Biorąc pod uwagę założenia i wymowę ideową Krzyżaków, zawarty w nich dychotomiczny podział na wartości polskie i antywartości niemieckie można potraktować szerzej i odnieść do opozycji my (swoi, sprzymierzeńcy) - oni (obcy, wrogowie), uznawanej przez kognitywistów oraz badaczy stereotypów i perswazji w języku za podstawowy kontrast kulturowy, który w sposób etnocentryczny pozwala postrzegać siebie i innych ${ }^{3}$.

${ }^{1}$ S. Kuczyński, Rzeczywistość historyczna w „Krzyżakach” Henryka Sienkiewicza, Warszawa 1963 , s. 9.

2 Ibidem, s. 7-8.

${ }^{3}$ Zob. J. Bartmiński, Jak zmienia się stereotyp Niemca w Polsce?, „Przegląd Humanistyczny" 1994, nr 5; H. Popowska-Taborska, Językowe wykładniki opozycji swoi-obcy w procesie tworzenia się etnicznej świadomości, w: Językowy obraz świata, red. J. Bartmiński, Lublin 1980; A. Niewiara, Wyobrażenia o narodach w pamiętnikach i dziennikach z XVI-XIX wieku, Katowice 2000; oraz bardzo obszerna literatura poświęcona teorii i praktyce perswazji językowej, np. I. Kamińska-Szmaj, Judzi zohydza, ze czci odziera. Jezzk propagandy politycznej w prasie 1919-1923, Wrocław 1993; L. Mariak, Perswazyjność prasy tajnej okresu Powstania Styczniowego 
Celem tego artykułu jest prześledzenie językowych sposobów wartościowania wykreowanych w powieści realiów (fikcyjnych i historycznych) związanych $\mathrm{z}$ obydwoma obozami ${ }^{4}$, to z kolei ujawni mechanizmy perswazyjne zastosowane przez H. Sienkiewicza w celu wpłynięcia na postawy i system wartości czytelników powieści. Pośrednio możliwe będzie także odtworzenie postawy wobec życia i systemu wartości samego autora, bo jak pisze Jadwiga Puzynina, „niewątpliwie autorskim aktem mowy (najczęściej wartościującym) jest całość utworu" "Założenie to ma swoje uzasadnienie również w przyjętym na użytek tego tekstu rozumieniu stylu językowego pisarza. Za Stanisławem Gajdą definiuję idiostyl jako ,humanistyczną strukturę tekstu”, w której to „sposób widzenia świata determinuje obróbkę tworzywa językowego, a „stosunek mówiącego do języka jest wtórny, warunkuje go prymarne odniesienie do rzeczywistości"'.

Zastosowane przez pisarza różne środki i mechanizmy wartościowania w opisie realiów polskich oraz niemieckich ujawniają się na każdym poziomie tekstu i obejmują zarówno sferę treści, jak i sferę wyrażania. Całość wyekscerpowanego materiału łączy wspólna cecha - wyraźnie zaznaczona waloryzacja (dodatnia lub ujemna) wyrażona w sposób bezpośredni lub pośredni oraz brak ocen niejednoznacznych. Repertuar użytych w powieści środków leksykalno-semantycznych służących wartościowaniu obejmuje następujące elementy:

- ciagi synonimiczne nazywające przedstawicieli obu nacji;

- nazwy wartości (pozytywne lub negatywne) oraz określenia działań, cech i postaw ludzkich ocenianych dodatnio lub ujemnie, w tym również pojęć o pejoratywnej lub melioratywnej treści, np. pycha, zbrodnia (in minus), poświęcenie, miłość (in plus), wchodzących w skład pól wyrazowych wartości łączonych z kategorią Polaka i Niemca;

- łączliwość nazw bliskoznacznych z rzeczownikiem, wyrażeniem przyimkowym, przymiotnikiem oraz czasownikiem wykorzystane w celu podkreślenia przymiotów obu narodów;

na przykladzie leksyki, Szczecin 2001; A. Markowski, Style perswazyjno-propagandowe, w: idem, Polszczyzna końca XX wieku, Warszawa 1992.

${ }^{4}$ Zważywszy na fabułę Krzyżaków, której centrum stanowi konflikt polsko-krzyżacki na przełomie XIV i XV wieku, wszystkie postacie zaludniające powieść można podzielić na dwa przeciwne obozy: niemiecki, do którego należą: Niemcy (zwłaszcza rycerze krzyżaccy), słudzy zakonni, goście (obcy rycerze) i inni zwolennicy Zakonu, oraz polski, do którego należą: Polacy (głównie polskie rycerstwo), Litwini, Żmudzini i inni popierający polską politykę w tym czasie. Pisząc o polskim lub niemieckim obozie, mam na myśli takie właśnie rozróżnienie.

5 J. Puzynina, Język wartości, Warszawa 1992, s. 134.

${ }^{6}$ S. Gajda, O pojęciu idiostylu, w: Język osobniczy jako przedmiot badań lingwistycznych, red. J. Brzeziński, Zielona Góra 1988, s. 25. 
- wypowiedzenia o określonych konotacjach (pozytywnych lub negatywnych) informujące o działaniach, zachowaniach i wyglądzie zewnętrznym postaci;

- środki stylistyczne, takie jak: porównania, metafory, epitety użyte w funkcji ekspresywnej i wartościującej.

Przed przystapieniem do analizy materiału leksykalnego konieczne jest zdefiniowanie pojęć ,wartość” i „,wartościowanie” w języku. Na użytek tego tekstu uwzględniłam definicje zaproponowane przez Elżbietę Laskowską, która wartość pojmuje jako „,echę w skali dobry - zły przypisywaną przedmiotowi (obiektowi) przez osobę (subiekta) ze względu na pewne kryterium"7, wartościowanie zaś określa jako „sąd wartościujący polegający na przypisywaniu wartości jakiemuś przedmiotowi"8. Przyjęte założenia badawcze (w tym zwłaszcza pojemne znaczeniowo definicje najważniejszych pojęć) pozwoliły na szeroki i wieloaspektowy ogląd zebranego materiału.

\section{Synonimiczne nazwy osobowe w funkcji wartościującej}

Mając na względzie powyższe ustalenia, proponuję, by przegląd środków językowo-stylistycznych użytych w funkcji oceniającej ${ }^{9}$ rozpocząc od nazw synonimicznych określających przedstawicieli obu obozów. Rejestr zebranych synonimów prezentuje tabela 1 .

Już pierwszy ogląd wymienionych przykładów pozwala zauważyć dwie tendencje wynikające z semantyki tych określeń. Pierwsza dotyczy znacznej przewagi nazw ekspresywnych nad neutralnymi, druga wskazuje na większą liczbę określeń nacechowanych ujemnie, w porównaniu z nazwami waloryzowanymi dodatnio. Ma to związek z faktem, że wartościowaniu zwykle towarzyszy wykładnik nacechowania emocjonalnego (dodatni lub ujemny): ocena negatywna łączy się z emocjami dezaprobaty, np. oburzenia, potępienia, z ocenami pozytywnymi zaś związane są emocje aprobaty, np. zachwytu, podzi$\mathrm{wu}^{10}$. Relacje między wartościowaniem pozytywnym i negatywnym wynikają z ogólnych założeń systemowych polszczyzny, która zdaniem J. Puzyniny ${ }^{11}$ oraz

7 E. Laskowska, Wartościowanie w języku potocznym, Bydgoszcz 1993, s. 13.

8 Ibidem, s. 20.

9 W niniejszej pracy ze względów stylistycznych będę używać zamiennie określeń: wartościowanie - ocenianie, powołując się na stanowisko E. Laskowskiej, która terminy te traktuje jako synonimiczne (z pewnymi zastrzeżeniami) (E. Laskowska, op.cit., s. 20).

10 Zob. R. Grzegorczykowa, Struktura semantyczna wyrażeń ekspresywnych, w: Z zagadnień słownictwa współczesnego języka polskiego, red. M. Szymczak, Warszawa 1979, s. 121.

11 J. Puzynina, Z historii słownictwa aksjologicznego w językach słowiańskich, w: Z polskich studiów slawistycznych, red. M. Basaj, Warszawa 1983, s. 281. 
Tabela 1. Synonimiczne określenia przedstawicieli swoich i obcych

\begin{tabular}{|c|c|c|c|c|c|}
\hline \multicolumn{3}{|c|}{ Polacy (my, swoi) } & \multicolumn{3}{|c|}{ Krzyżacy (oni, obcy) } \\
\hline $\begin{array}{c}\text { nazwy } \\
\text { neutralne }\end{array}$ & $\begin{array}{c}\text { nazwy } \\
\text { wartościujące }^{12}\end{array}$ & $\begin{array}{c}\text { nazwy } \\
\text { nacechowane }\end{array}$ & $\begin{array}{c}\text { nazwy } \\
\text { neutralne }\end{array}$ & $\begin{array}{c}\text { nazwy } \\
\text { wartościujące }\end{array}$ & $\begin{array}{c}\text { nazwy } \\
\text { nacechowane }\end{array}$ \\
\hline $\begin{array}{l}\text { król, lud, } \\
\text { monarcha, } \\
\text { naród, } \\
\text { plemie, } \\
\text { Polak, rycerz }\end{array}$ & $\begin{array}{l}\text { nieprzyja- } \\
\text { ciel, wróg } \\
\text { (Krzyżacy } \\
\text { o Polakach) }\end{array}$ & $\begin{array}{l}\text { ciało stowiańskie, } \\
\text { dziedzice } \\
\text { 'polscy rycerze', } \\
\text { krew polska, } \\
\text { młodzianek, } \\
\text { zwierciadto czci, } \\
\text { najstynniejszy } \\
\text { między stynnymi, } \\
\text { wzór rycerzy } \\
\text { 'Zawisza', } \\
\text { zwycięskie, } \\
\text { krwawe polskie } \\
\text { ręce } \\
\text { oraz: drapieżnik, } \\
\text { tamignat, } \\
\text { niszczyciel, pies, } \\
\text { wilk'Jurand' } \\
\text { (określenia użyte } \\
\text { przez rycerzy } \\
\text { zakonnych } \\
\text { w stosunku do } \\
\text { Juranda, którego } \\
\text { uważali za swego } \\
\text { największego } \\
\text { wroga) }\end{array}$ & $\begin{array}{l}\text { brat, komtur, } \\
\text { mnich, } \\
\text { Niemiec, } \\
\text { pan, plemię, } \\
\text { rycerz, } \\
\text { Zakon }\end{array}$ & $\begin{array}{l}\text { nieprzyja- } \\
\text { ciel, wróg, } \\
\text { zdrajca } \\
\text { (Polacy } \\
\text { o Krzyża- } \\
\text { kach) }\end{array}$ & $\begin{array}{l}\text { chuchrak, kat, } \\
\text { Krzyżak- } \\
\text { krzywdziciel, } \\
\text { krzywoprzysięzca, } \\
\text { krzyżacka jucha, } \\
\text { krzyżacka mać } \\
\text { 'przekleństwo', } \\
\text { tgarz, morderca, } \\
\text { okrutnik, piekiel- } \\
\text { nik, pies, potega, } \\
\text { powódź, pożoga, } \\
\text {,przednia straż' } \\
\text { teutońska, psu- } \\
\text { brackie pazury, } \\
\text { psubrat, rabuś, } \\
\text { smok, szelma, } \\
\text { truteń, waligóra } \\
\text { 'rycerz Arnold', } \\
\text { waż, wilk 'Zakon', } \\
\text { wilcza morda } \\
\text { 'Zygfryd', } \\
\text { wilkołak, zaraza, } \\
\text { zbój, zbój-rycerz, } \\
\text { zdrajca-Niemiec } \\
\text { oraz: olbrzym } \\
\text { 'rycerz Arnold', } \\
\text { owieczki zakonne, } \\
\text { wzór i ozdoba } \\
\text { rycerstwa 'Ulryk } \\
\text { von Jungingen' } \\
\text { (określenia użyte } \\
\text { przez rycerzy za- } \\
\text { konnych w sto- } \\
\text { sunku do swoich } \\
\text { współbraci) }\end{array}$ \\
\hline
\end{tabular}

E. Laskowskiej ${ }^{13}$ zawiera więcej określeń wartości negatywnych niż pozytywnych, a to z kolei przekłada się na sposób ich postrzegania. Antywartości, w odróżnieniu od wartości pozytywnych, traktowane są jako elementy odbiegające od normy i w związku z tym są bardziej widoczne i częściej werbalizowane.

${ }^{12}$ Zaliczam tu nazwy, które zawierają wyraźnie określony element znaczeniowy „źle” i charakteryzują się negatywnymi konotacjami wynikającymi ze znaczenia wyrazów (zob. R. Grzegorczykowa, op.cit., s. 119).

${ }^{13}$ E. Laskowska, op.cit., s. 13. 
Ponadto, pamiętać należy, że ekspresywizacja i ocenianie należą do podstawowych mechanizmów wykorzystywanych w działaniach perswazyjnych, których zadaniem jest wpłynięcie na postawy i system wartości odbiorców, a taki cel niewątpliwie przyświecał H. Sienkiewiczowi przy pisaniu Krzyżaków.

Wymienione w tabeli nacechowane nazwy (proste, analityczne, realnoznaczeniowe oraz przenośne) prócz nominacji niosły także wartościowanie, któremu towarzyszył duży ładunek emocji. Elementem decydującym o wartości ekspresywnej tych określeń był nie tyle kontekst (jego rola sprowadzała się raczej do podkreślenia oceny zawartej w strukturze wyrazu), ile konotacje (negatywne lub pozytywne) wynikające ze znaczenia leksemów. I tak nazwy realnoznaczeniowe, takie jak: krzywdziciel, tgarz, morderca, okrutnik, rabuś, szelma, zbój, wskazywały na niemoralne i nieludzkie metody działania rycerzy zakonnych na zajętych ziemiach w stosunku do zamieszkującej tam ludności. Przykłady metaforycznych określeń w przeważającej większości wskazują na wykorzystanie depersonifikującej roli nieosobowych nazw pospolitych, które reifikowały, a tym samym deprecjonowały postacie rycerzy krzyżackich. W wyniku przekształceń semantycznych zastosowanych przez H. Sienkiewicza zostały im przypisane cechy:

- zwierząt: pies, truten', waż, wilk 'Zakon', żmija 'służka zakonna';

- fantastycznych istot kojarzonych ze złem: smok, wilkołak;

- żywiołów i plag: powódź, pożoga, zaraza;

- groźnej siły: potega (krzyżacka, niemiecka);

- ludzi nieaprobowanych przez społeczeństwo, których profesja bądź zachowanie budziły strach: kat, piekielnik, truciciel.

Jak widać z powyższych przykładów, w nazywaniu rycerzy krzyżackich, H. Sienkiewicz użył przede wszystkim nacechowanych ekspresywnie animalizacji i wykorzystał je w funkcji językowych wykładników deprecjacji. Do tej kategorii określeń można by zaliczyć także metonimię: psubrackie pazury 'rycerze krzyżaccy, którzy uprowadzili Danusię’: „Czech zaś rzekł: - Myślałem i jeszcze myślę, że z tych psubrackich pazurów nie wyrwiemy jej żywej, ale wszystko w boskich rękach" (II, 177) ${ }^{14}$, oraz - ciekawą ze względu na odniesienia kontekstowe i nośność perswazyjną - peryfrazę nazwy Zakon: przednia straż teutońska: „Padł pod stopami wielkiego króla nie tylko Zakon krzyżacki, ale i całe Niemcy, które najświetniejszym rycerstwem wspomagały oną «przednią straż» teutońską, wżerającą się coraz głębiej w ciało słowiańskie" (II, 534). Teutonowie było to plemię germańskie zamieszkujące Półwysep Jutlandzki, które zaatakowało państwo rzymskie, ale wkrótce po

${ }^{14}$ Liczba rzymska oznacza tom, arabska numer strony. Korzystam z wydania: H. Sienkiewicz, Krzyżacy, t. 1-2, Warszawa 1954. Tekst oparty na zbiorowym wydaniu Dziet Henryka Sienkiewicza, red. J. Krzyżanowski, Warszawa 1948. 
tym wydarzeniu zostało całkowicie pokonane ${ }^{15}$. Przywołanie powinowactwa starożytnego plemienia germańskiego, jako odniesienia motywującego losy Zakonu krzyżackiego w bitwie grunwaldzkiej, można uznać za celowy zabieg perswazyjny, którego funkcja i uniwersalne przesłanie były łatwe do odczytania dla dziewiętnastowiecznego czytelnika. Wartość ekspresywną tej metafory wzmacnia dodatkowo kontekst i usytuowanie w podniosłym epilogu opisującym tragiczne dla Zakonu, a zwycięskie dla Polaków skutki bitwy na polach Grunwaldu. Według Aleksandry Niewiary ${ }^{16}$ w XIX wieku znaleźć można wiele określeń przypominających, wartościowaną negatywnie (bowiem łączoną z takimi cechami, jak: okrucieństwo, pycha) germańską przeszłość Niemców. H. Sienkiewicz, prezentując Krzyżaków jako następców germańskich plemion, odwołał się do ogólnej tendencji żywej w dziewiętnastowiecznej polszczyźnie oraz do stereotypowych wyobrażeń ówczesnych Polaków na temat genezy narodu niemieckiego.

Konstrukcje peryfrastyczne i metonimiczne, takie jak: krew polska, zwierciadło czci 'Zawisza', ciało słowiańskie, były charakterystyczne także dla nominacji przedstawicieli narodu polskiego. W przedstawionych przykładach interesująca jest zwłaszcza ostatnia metafora: ciało słowiańskie, która podobnie jak inne epitety określające Polaków, np.: polskie plemię (II, 532); lechickie plemię (II, 195); nasze plemię (II, 434); całe plemię (II, 465), nasz naród (I, 296), wskazują, że H. Sienkiewicz przyjął punkt widzenia Słowianina przy wprowadzaniu ocen własnego narodu. Zgodnie z tym stanowiskiem przynależność do narodów słowiańskich, stereotypowo postrzeganych jako cywilizowane, konotowało zawsze dodatnią ewaluację. Odwołanie się do tego wyobrażenia sprawiło, że w kreacji świata przedstawionego w powieści wyraźnie zostało rozgraniczone to, co słowiańskie, lechickie, polskie (dobre), od tego, co niemieckie, germańskie, krzyżackie (złe). Konflikt polsko-krzyżacki, jako najważniejszy element fabuły powieści, nabrał w związku z tym znaczenia uniwersalnego i ponadczasowego. Zdaniem A. Niewiary ${ }^{17}$ „słowianofilski aspekt” postrzegania siebie i innych nacji jest stosunkowo nowy, bowiem ugruntował się w kulturze polskiej i świadomości Polaków dopiero w XIX wieku. O jego istnieniu w tym czasie świadczą nie tylko ówczesne pamiętniki i dzienniki (o czym pisze autorka), ale także moje badania nad tekstami prasy tajnej okresu powstania styczniowego ${ }^{18}$.

15 Nowa encyklopedia powszechna PWN, t. 6, Warszawa 1997.

16 A. Niewiara, Wyobrażenia o narodach..., s. 151.

17 A. Niewiara, Inni w oczach ,wojowników sarmackich” - o stereotypie narodowości w XVII wieku, w: Stereotyp jako przedmiot lingwistyki. Teoria, metodologia, analizy empiryczne, red. J. Anusiewicz, J. Bartmiński, Język a Kultura, t. 12, Wrocław 1998, s. 179.

18 Zob. L. Mariak, Perswazyjność prasy tajnej..., s. 129-130. 
Wśród zgromadzonych nazw analitycznych znalazły się także połączenia apozycyjne typu: Krzyżak - krzywdziciel, zdrajca - Niemiec, zbój-rycerz. Konstrukcje tego typu są charakterystyczne tylko dla nominacji przedstawicieli krzyżackiego obozu, dlatego wnoszą wyraźnie pejoratywną ocenę i ujemną ekspresję. Pod względem typologicznym dominują tu zestawienia indywidualizujące ${ }^{19}$, których zadaniem było wyodrębnienie i precyzyjne dookreślenie negatywnych cech prezentowanych osób.

Cechą charakterystyczną przedstawionego zbioru nazw jest wyraźna dysproporcja w liczbie eksplicytnych określeń wartościujących, których H. Sienkiewicz użył w stosunku do Polaków i Krzyżaków. Znaczna przewaga określeń rycerzy krzyżackich nie oznacza, że pisarz zminimalizował przykłady świadczące o ocenianiu postaci polskich. Wartościowanie w tym wypadku zostało przeprowadzone w pośredni, opisowo-wartościujący sposób, głównie przez użycie nazw neutralnych, tylko konotacyjnie wartościujących, typu: chłop 'rycerz', lud, monarcha, naród, plemię, rycerz, oraz odpowiednio waloryzującego kontekstu, np.: mocarny chłop (II, 456); twardy nasz naród 'wytrzymały na trudy wojenne'; zacni monarchowie 'Witold i Jagiełło'; prosty, czerstwy nasz naród; wolny lud; rycerz: potężny 'silny, muskularny' (II, 342), prawy (I, 71), sławny (II, 339), stynny (II, 201), szlachetny (II, 164) i inne. Najważniejszym elementem oceniającym w tych przykładach są przymiotniki związane z określonymi kategoriami wartości ${ }^{20}$, spośród których najliczniej reprezentowane są: wartości moralne, np.: szlachetny, zacny, prawy, prosty; witalne: czerstwy, mocarny, potężny oraz społeczne: sławny, stynny.

W kontekstach określających rycerzy zakonnych (neutralnych, nacechowanych i wartościujących) również występują przymiotniki nacechowane ewaluacyjnie. Zgodnie z dychotomicznym podziałem są one związane z polem wyrazowym antywartości. Najczęściej pojawiają się tu określenia cech i postaw ludzkich wskazujących na sprzeczność z ogólnie pojmowanym dobrem moralnym i etycznym, np.: drapieżny zbój-rycerz niemiecki (II, 374); nieprzyjaciel // wróg: mściwy (II, 72); nieprawy (II, 497); najzawziętszy (II, 58); nieubłagany (II, 7); ludzie: okrutni (II, 133); zdradliwi (II, 355); psi bezecni (II, 212); przeniewierczy Zakon (II, 539). Wymienić tu należy także przymiotniki ogólnie wartościujące, z wpisanym semem intensywności cechy, np.: straszny wróg, najgorszy pies; wraże plemię. Prócz przymiotników eksplicytnie wartościujących w funkcji tej występuja przymiotniki nienacechowane typu: polski, lechicki, litewski, słowiański, krzyżacki, niemiecki oraz zaimek dzierżawczy

${ }^{19}$ S. Jodłowski, Zestawienia bliźniacze, „Biuletyn Polskiego Towarzystwa Językoznawczego" XXI, 1962, s. 56-60.

${ }^{20}$ Zob. typologię kategorii wartości zaproponowaną przez J. Puzyninę Język wartości, s. 149-182 i E. Laskowską, op.cit., s. 14-19. 
nasz, które to formy ze względu na kontekst oraz wymowę ideową powieści wnoszą ewaluację pozytywną lub negatywną, wynikającą z dwubiegunowego wartościowania opartego na opozycji swój - obcy: „wszystko tu [na Żmudzi L.M.] było grubsze, surowsze [...], bardziej przeciw nowościom zawzięte [...], a i pogaństwo uporczywsze, dlatego że czci Krzyża nauczał nie łagodny zwiastun Dobrej Nowiny z miłością apostoła, lecz zbrojny niemiecki mnich z duszą kata" (II, 207); ,ale to jeno ci muszę powiedzieć, że u nas przecie polski kraj i że za przemoc nad dziewką okrutne są kary w statucie" (II, 106).

Podobną funkcję waloryzującą i zarazem precyzującą spełniają użyte w tekście przydawki przyimkowe i dopełniaczowe określające rzeczownikowe nadrzędniki wypowiedzeń, np.: zbóje z krzyżem na plaszczach (I, 433); kat Witoldowych dzieci 'brat Szomberg' (I, 433); nieprzyjaciele naszego plemienia (I, 239).

$\mathrm{Na}$ zakończenie prezentacji bliskoznacznych nazw osobowych, warto zwrócić uwagę na dość często wykorzystywany przez H. Sienkiewicza sposób nadawania wartości (dodatniej lub ujemnej) nazwom przez odpowiednio dobrany kontekst. Najczęściej mechanizm ten stosowany był w przypadku nazw uznawanych w języku ogólnym za neutralne, np.: brat, plemię, rycerz, naród, które dzięki kontekstowi zyskiwały walor ekspresywny, np.:

Krzyżacy, wiecznie Krzyżacy! Myśli Maćka i Jagienki ulatywały ustawicznie ku Zbyszkowi, który przebywał właśnie jakoby w paszczy wilczej, wśród wrażego plemienia nie znającego ni litości, ni praw gościnnych. Sieciechównie mdlało także serce, nie była bowiem pewna, czy [...] nie przyjdzie im aż między tych okrutnych ludzi zajechać... (I, 133) $(-)^{21}$

- Iżeś trzy pawie czuby poprzysiagł, to ich sobie szukaj! Chwalebny to jest i Bogu miły uczynek nieprzyjaciół naszego plemienia ścigać. (I, 239) (+)

Chłop, przyzwyczajony więcej do razów niż do datków z rąk miejscowych krzyżackich rycerzy, oczom prawie nie chciał wierzyć i porwawszy pieniądz, przypadł głową do strzemienia Juranda [...]. (I, 447) (-)

- To pan de Lorche tu jest?

- Gdzie by miał być? [...]

- Rad go obaczę, bo to rycerz, któremu w niczym nie przyganić. (II, 396-397) (+)

Ewaluacja znaczeń nazw zależała nie tylko od kontekstu, wpływ na nią miała także przyjęta perspektywa oceny: z pozycji obcych lub przedstawicie-

${ }^{21}$ Symbole $(-),(+)$ oznaczają wartościowanie odpowiednio ujemne lub dodatnie leksemów. 
li własnej grupy, np. dla Krzyżaków Jurand był łamignatem, niszczycielem, psem, wilkiem, Polacy to: złośliwi ludzie (I, 435), pogańscy bracia (II, 13), wilcze plemie (II, 22). Swoich zaś towarzyszy nazywali: owieczkami zakonnymi, stugami Chrystusowymi, rycerzami Chrystusa, chrześcijańskimi rycerzami, mistrz zakonny był dla nich wzorem i ozdoba rycerstwa. Taki sposób wartościowania dowodzi subiektywizmu w ocenie i wyraźnego rozgraniczenia na swoich i obcych.

\section{Nazwy wartości i wyrażenia wartościujące}

Podobnie jak w przypadku synonimicznych nazw osobowych, tak i tu można zauważyć wyraźnie manichejski podział na wartości pozytywne i wartości negatywne. Tworzą one antynomiczne pary w obrębie pól wyrazowych, których hiperonimami są dwa skrajnie przeciwne pojęcia: dobro i zło ${ }^{22}$.

O ile pojęcie zła ma zawsze jednoznacznie negatywną ewaluację i zawsze w takim kontekście jest umieszczane, o tyle pojęcie dobra jest tu kategorią względną i może być interpretowane, w zależności od kontekstu, jako dobro „prawdziwe” lub dobro „fałszywe, pozorne”, np.:

\section{Zlo}

Każdy na swoim zamku jako książę udzielny siedzi - i jeden drugiemu w złem pomaga. Poskarżym się mistrzowi - a oni się zaprą. Mistrz każe im dziewkę oddać, a oni nie oddadzą - albo też rzekną: „Nie masz jej u nas, bośmy jej nie porywali”. Każe im przysiąc, to i przysięgną. Co tedy nam robić? $(\mathrm{I}, 416)$

Nie przejedna Zakonu ni słaby, ni mocny, bo słabym gardzą, mocnego zaś do upadku przywieść usiłują. Kto im dobrze uczyni, temu się złem wypłacą. (I, 49-50)

\section{dobro ,prawdziwe"}

Po czym łzy ciurkiem jęły płynąć po twarzy Jagienki, bo bardzo kochała opata, który choć zapalczywy z ludźmi, krzywdy nie wyrządził nikomu, a dobro obu rękoma czynił [...]. (II, 139)

${ }^{22}$ Rozumienie pojęć: dobro // zło przejmuję za J. Puzyniną, według której „zdanie: X jest dobre znaczy: X jest takie, jakie (ludzie w ogóle, pewna ich grupa i) nadawca chce (chca), żeby $\mathrm{X}$ było. I analogicznie: $\mathrm{X}$ jest złe $-\mathrm{X}$ jest takie, jakie (ludzie w ogóle, pewna ich grupa i) nadawca chce - nie chce (chca), żeby X było" (J. Puzynina, Jak pracować nad językiem wartości?, w: Zagadnienia leksykalne i aksjologiczne, red. J. Bartmiński, J. Puzynina, Wrocław 1991, Język a Kultura, t. 2, s. 132). 
Zbyszko dziękował mu też z całej duszy, gdyż teraz był już zupełnie pewien, że Maćka z rąk krzyżackich wydostanie.

- Tobie niejeden zajrzy - mówił mu - że przy majestacie zostajesz, ale to sprawiedliwie tak jest, bo jeno na dobro ludzkie swojej podufałości z królem używasz i lepszego nad cię serca nikt chyba nie ma. (II, 363)

\section{dobro „falszywe"}

Nie znają Krzyżacy bojaźni Bożej i swego dobra tylko patrzą [...]. (I, 160)

Brat Szomberg i brat Markwart czuwają nad panienka, przeto wy, panie, hamujcie swój gniew... Ale nie stanie się jej nic złego, bo choć przez wiele lat krzywdziliście ciężko Zakon, jednakże bracia chcą wam dobrem za złe wypłacić, jeśli uczynicie zadość sprawiedliwym ich żądaniom. (I, 434)

Hugo von Danveld zbliżył się do Danusi, położył dłoń na jej głowie i głaszcząc ja, rzekł: - Nam przykazano dobrem za złe płacić i miłować nawet nieprzyjaciół naszych, więc przyjedzie tu siostra zakonna i przywiezie wam, panienko, gojący balsam hercyński. (I, 347)

O fałszywości „dobra”, na które tak często i chętnie powoływali się Krzyżacy, świadczyć mogą ich wcześniejsze niecne czyny. Bracia Szomberg i Markwart wsławili się tym, że porwali i z zimną krwią zamordowali dzieci księcia Witolda, Hugo Danveld zaś miał opinię największego rozpustnika w Zakonie. W tym kontekście postępowanie ich należy postrzegać nie w kategorii czynionego dobra, lecz wyrachowanego zła, którego celem miała być zemsta na Jurandzie. Wydaje się, iż celem takiego sposobu prezentowania postaci Krzyżaków była chęć napiętnowania krzyżackiej hipokryzji oraz obnażenie prawdziwych intencji ich działań, a na płaszczyźnie językowej - zwiększenie nośności perswazyjnej tych wypowiedzi. Zabieg ten można potraktować jako swego rodzaju grę językową, której zasady odnoszą się do wspólnoty wiedzy i doświadczeń piszącego i czytelnika.

Na wykreowany w powieści świat wartości złożyły się przede wszystkim te, które miały związek z moralnością i etyką pojmowaną w wymiarze chrześcijańskim. Pozostałe kategorie wartości, np. pragmatyczne, estetyczne, społeczno-obyczajowe mieszczą się w ogólnospołecznym kanonie podstawowych wartości moralnych. Centralnym pojęciem tej kategorii jest dobro drugiego człowie$\mathrm{ka}^{23}$. Tabela 2 rejestruje przykłady nazw wartości moralnych wraz z określeniami cech i działań ludzkich, postrzeganych jako moralnie pozytywne.

${ }^{23}$ Typologię wartości przyjmuję za J. Puzyniną, Jak pracować..., s. 132-136; eadem, Język wartości, s. 149-182. 
Tabela 2. Określenia wartości moralnych

\begin{tabular}{|c|c|}
\hline $\begin{array}{l}\text { Nazwy wartości oraz } \\
\text { działań, cech i postaw } \\
\text { ludzkich moralnie } \\
\text { pozytywnych }\end{array}$ & Egzemplifikacja \\
\hline prawda & $\begin{array}{l}\text { W głosie jego [Juranda-L.M.] tyle było rozpaczy i prawdy, że } \\
\text { niektórzy poczęli się domyślać podstępu [...]. (II, 15) }\end{array}$ \\
\hline \multirow[t]{2}{*}{ miłosierdzie; łaska } & $\begin{array}{l}\text { noc spędzona w spychowskim więzieniu, i niepewność losu, } \\
\text { a nade wszystko ów niesłychany, nadludzki niemal czyn laski } \\
\text { i milosierdzia, który po prostu go [Zygfryda] przeraził, wszystko to } \\
\text { potargało go do ostatka. (II, 303) }\end{array}$ \\
\hline & $\begin{array}{l}\text { Zbyszko ujrzał liliową twarz [królowej Jadwigi - L.M.] rysy po prostu } \\
\text { anielskie, pełne spokoju, dobroci, milosierdzia [...]. (I, 91) }\end{array}$ \\
\hline \multirow[t]{2}{*}{ pokój } & $\begin{array}{l}\text { Mogli mądrzy panowie krakowscy i miłujący pokój król hamować te } \\
\text { siły do czasu i odkładać wojnę z odwiecznym wrogiem na długie lata } \\
\text { [...]. (II, 451) }\end{array}$ \\
\hline & $\begin{array}{l}\text { Królowi ciágle śluzy do oczu płyną na myśl, że tyle się krwie } \\
\text { chrześcijańskiej rozleje i do ostatniej chwili rad by sprawiedliwy } \\
\text { pokój zawrzeć, ale pycha krzyżacka do tego nie dopuści. (II, 489-490) }\end{array}$ \\
\hline \multirow[t]{2}{*}{ wolność; wolny } & $\begin{array}{l}\text { „Słuchajcie, słuchajcie! - wołali do królów, książąt i wszystkich } \\
\text { narodów Żmujdzini. - Wolnym ci my byli i szlachetnej krwi ludem, } \\
\text { a Zakon chce nas w niewolników przemienić! (II, 195) }\end{array}$ \\
\hline & $\begin{array}{l}\text { Tolima [...] dopiero gdy pomyślał, że Jurand nie do granicy tylko } \\
\text { darował życie i wolność jeńcowi, [...] przezwyciężył się i [...] rzekł: } \\
\text { - Oto granica nasza, a i do waszej niedaleko. Jedźże wolny [...]. (II, 302) }\end{array}$ \\
\hline \multirow[t]{4}{*}{$\begin{array}{l}\text { odwaga; męstwo, } \\
\text { dzielność, dzielny, } \\
\text { odważnie }\end{array}$} & $\begin{array}{l}\text { on [Zbyszko - L.M.] pomyślał widocznie, że wobec tych tłumów [...] } \\
\text { trzeba umrzeć odważnie i zostawić po sobie przynajmniej pamięć } \\
\text { „,dzielnego chłopa”, więc wytężył całą odwagę i wolę [...]. (I, 144) }\end{array}$ \\
\hline & $\begin{array}{l}\text { Przyniosła mężowi [Jagienka - L.M.] wielkie wiano [...] i dworność, } \\
\text { i dzielność taką, że niejeden rycerz mógłby się nią pochlubić. (II, 449) }\end{array}$ \\
\hline & $\begin{array}{l}\text { rozgrzmiała po całym kraju radosna wieść, że dzielny Kiejstutowicz } \\
\text { wziął Nowe Kowno [...]. (I, 429) }\end{array}$ \\
\hline & $\begin{array}{l}\text { Witold przyjął wreszcie Żmujdź w jawną opiekę, wysłał swych } \\
\text { rządców, a wodzem zbrojnemu ludowi ustanowił słynnego z męstwa } \\
\text { Skirwoiłłę. (II, 194) }\end{array}$ \\
\hline
\end{tabular}

Po przeciwnej stronie dyferencjału semantycznego znajduje się kategoria antywartości moralnych, których centralnym pojęciem jest krzywda drugiego człowieka $^{24}$ (tab. 3).

${ }^{24}$ J. Puzynina, Język wartości, s. 160. 
Tabela 3. Określenia antywartości moralnych

\begin{tabular}{|c|c|}
\hline $\begin{array}{l}\text { Nazwy antywartości } \\
\text { oraz czynności, cech } \\
\text { i postaw moralnie } \\
\text { negatywnych }\end{array}$ & Egzemplifikacja \\
\hline $\begin{array}{l}\text { fałsz, } \\
\text { kłamstwo, } \\
\text { nieprawość; } \\
\text { krzywoprzysięstwo, } \\
\text { kłamać, kłamliwy, } \\
\text { matactwa, wykręty, } \\
\text { (ze)łgać }\end{array}$ & $\begin{array}{l}\text { owo przeświadczenie, że Zakon stoi nie na prawie Bożym, ale na } \\
\text { nieprawości i kłamstwie [...] czyniło go jednym z najbardziej } \\
\text { nieszczęsnych ludzi w świecie. (II, 366) } \\
\text { Musiał kłamać, bo kłamstwo odziedziczył razem z oznakami } \\
\text { mistrzostwa, a od wczesnych lat przywykł uważać je tylko za } \\
\text { polityczną przebiegłość. (II, 364) } \\
\text { jego [Zygfryda - L.M.] dusza krzyżacka, chociaż z natury } \\
\text { więcej okrutna niż kłamliwa, tak już pod wpływem nieubłaganej } \\
\text { konieczności wzwyczaiła się do wykrętów, matactw i osłaniania } \\
\text { krwawych zakonnych postępków [...]. (II, 84) } \\
\text { Uśmiechali się pod wąsem z tych zapewnień Mazurowie, albowiem } \\
\text { dobrze znana im była chciwość zakonna, a jeszcze lepiej kłamstwa } \\
\text { Krzyżaków. Powtarzano na Mazowszu, że ,jako tchórz cuchnie, tak } \\
\text { Krzyżak łże”. (I, 347) } \\
\text { A Hugo de Danveld przyskoczył niemal z pięściami do pana de Fourcy. } \\
\text { - Po coś powiedział, że wyście pierwsi naśli Juranda? } \\
\text { - Bo prawda! } \\
\text { - Trzeba ci było zełgać. } \\
\text { - Jam tu przyjechał bić się, nie lgać. (I, 342) } \\
\text { Na to książę zwrócił się do Zygfryda i rzekł: } \\
\text { - Patrzcieże, w co się sprawiedliwość w waszych uściech obraca i zali } \\
\text { wasze wykręty nie obrażają Boga? (I, 337-338) } \\
\text { [Wolfgang - L.M.] dowiedział się o wszystkich szczytnieńskich } \\
\text { zbrodniach, krzywoprzysięstwach i zdradach, a zarazem o losach } \\
\text { nieszczęsnej Danusi. (II, 283) }\end{array}$ \\
\hline $\begin{array}{l}\text { okrucieństwo; } \\
\text { okrutnie }\end{array}$ & $\begin{array}{l}\text { Jeśli nawet dobro Zakonu nakazywało, jak chwilami na Żmujdzi, } \\
\text { większą łagodność - i takie nakazy szły wniwecz wobec niesforności } \\
\text { komturów i przyrodzonego im okrucieństwa. (II, 365) } \\
\text { w końcu [Krzyżacy - L.M.] okrutnie Litwę ogniem i mieczem } \\
\text { pognębili [...]. (I, 8) }\end{array}$ \\
\hline $\begin{array}{l}\text { krzywda; brak } \\
\text { miłosierdzia }\end{array}$ & $\begin{array}{l}\text { mieli bowiem przed sobą jawny dowód tego braku milosierdzia } \\
\text { i braku miary w karaniu, jakimi odznaczali się rycerze zakonni. (II, 157) } \\
\text { mówili o Jurandzie, o jego nieszczęsnym losie i niewypowiedzianych } \\
\text { krzywdach, jakich od Krzyżaków doznał [...]. (II, 162-163) }\end{array}$ \\
\hline $\begin{array}{l}\text { zdrada, zbrodnia; } \\
\text { gwałty }\end{array}$ & $\begin{array}{l}\text { Będzie się książę skarżył królowi polskiemu i wysłańcy ich nie omiesz- } \\
\text { kają krzyczeć na wszystkich dworach na nasze gwalty, na naszą zdradę, } \\
\text { na naszą zbrodnię. Ile może być z tego szkody dla Zakonu! (II, 26) }\end{array}$ \\
\hline
\end{tabular}




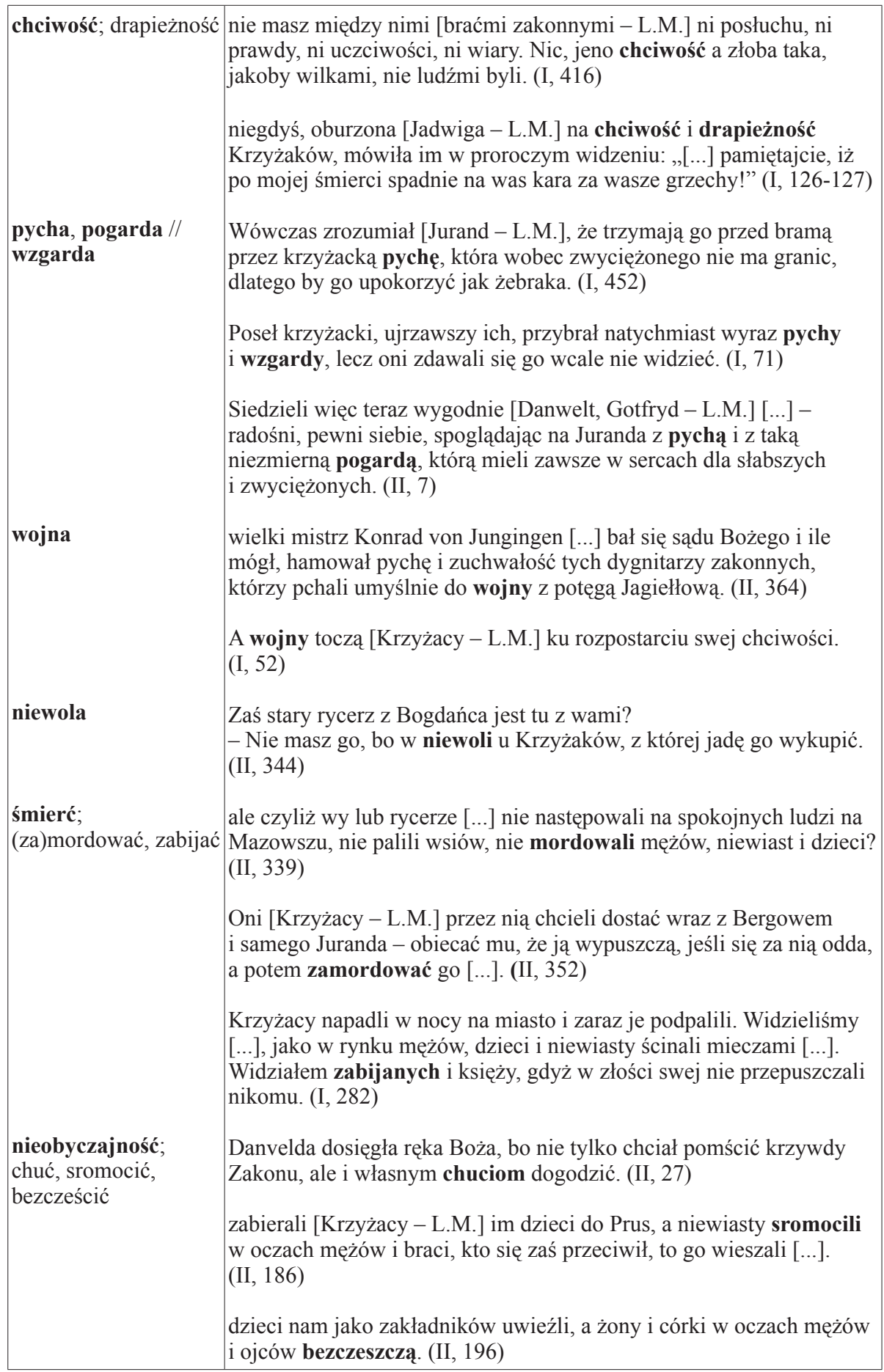


Przedstawiony w obu tabelach rejestr nazw wartości i antywartości moralnych oraz związanych z nimi cech i postaw ludzkich nie jest pełny. Ze względu na bogactwo i różnorodność materiału wybór ograniczono tylko do kategorii najbardziej reprezentatywnych. Można by tu oczywiście mówić o innych bardziej wyspecjalizowanych czynnościach, postawach i cechach moralnie aprobowanych lub nie, takich jak np.: poświęcenie, kochać, wspótczuć; rabować, (po)hańbić, mściwość i wiele innych. Wszystkie one wyraźnie informuja o postawach uczuciowo-woluntatywnych bohaterów służących dobru lub złu, pozwalają także na jednoznaczną ich identyfikację.

Ze względu na tematykę i opisywane w powieści średniowieczne realia równie ważne okazały się wartości: obyczajowo-społeczne, takie jak: honor, sława, przestrzeganie praw i cnót rycerskich, gościnność, transcendentalne, np.: wiara, Bóg, religia oraz pragmatyczne, np.: ziemia, dobra doczesne. $\mathrm{O}$ większości z nich pisałam wcześniej ${ }^{25}$, tu chciałabym zwrócić uwagę na ostatnią kategorię - wartości pragmatyczne. Jest ona ważna ze względu na odzwierciedlony w powieści „barwny obraz życia drobnej i średniej szlachty, zakres jej zainteresowań i celów, jej byt i gospodarkę"26. Zgodnie z wizerunkiem wykreowanym przez H. Sienkiewicza dbałość o ziemię, pomnażanie majątku postrzegane były jako działania pozytywne, ponieważ świadczyły o mądrości, zapobiegliwości i przyszłościowym myśleniu. Ponadto, ziemię i inne dostatki traktowano jako miernik znaczenia i pozycji społecznej ich właściciela:

Ludzie [...] opowiadali sobie aż do przesady zwłaszcza o bogactwach, które Bogdanieccy mieli wywieźć ze Spychowa. Mówiono, że pieniądze solówkami wozili z Mazowsza. Wygodził też raz Maćko pożyczką kilkunastu grzywien możnym dziedzicom na Koniecpolu, co do ostatka utwierdziło okolicę w mniemaniu o jego „skarbach”. Z tego powodu rosło znaczenie Bogdanieckich, rósł szacunek ludzki i gości nigdy nie brakło w kasztelu, na co Maćko, choć oszczędny, nie patrzał niechętnym okiem, gdyż wiedział, że i to sławy rodowi przymnaża. (II, 456)

Spośród wszystkich bohaterów powieści największym zainteresowaniem dobrami doczesnymi wykazał się Maćko z Bogdańca, jego chciwość na ziemię, łupy i inne bogactwa była znana w całej okolicy:

${ }^{25}$ L. Mariak, Obraz Boga w ,Krzyżakach Henryka” Sienkiewicza, „Studia Językoznawcze”, t. 5, 2006, s. 127-149; eadem, Językowe wyznaczniki opisu rycerza w „Krzyżakach” Henryka Sienkiewicza (Na przykładzie rzeczowników i grup nominalnych), „Studia z Filologii Polskiej i Słowiańskiej” 2007, t. 4, s. 73-94.

${ }^{26}$ S. Kuczyński, op.cit., s. 127. 
Tu Maćko, który był chciwy na ziemię i robociznę, począł marzyć:

- Boga mi! Przygnać tak z pięćdziesiąt chłopa i osadzić na Bogdańcu! Przetrzebiłoby się puszczy szmat. Uroślibyśmy oba! (I, 37)

I naród, i rody były na dorobku do wielkości. Znaczne mienie mogło tylko pomóc Zbyszkowi na tej drodze, więc chciwość i pycha rodowa Maćka miały się z czego cieszyć. (II, 93)

Wieźli natomiast moc pieniędzy i różnych bogactw, w znacznej części złupionych swego czasu na Niemcach [...]. Toteż Maćko, spoglądając teraz na ładowne, pokryte rogożami wozy, radował się w duszy na myśl, jak wspomoże i urządzi Bogdaniec. (II, 412)

Z perspektywy aksjologii średniowiecznej postępowanie i postawa Maćka (żądza bogactwa, zabieganie o dobra doczesne) mogłyby być ocenione negatywnie. Ideologia wieków średnich, oparta na przesłankach religijnych, odrzucała bogactwo jako źródło szczęścia. Pozytywnie wartościowano wówczas życie duchowe, wiarę, ubóstwo, służbę Bogu, to one zapewniały szczęście, zbawienie i życie wieczne. Sytuacja ta zmieniła się dopiero w następnej epoce. Jak pisze Johan Huizinga: „Protestantyzm i Odrodzenie użyczyły chciwości walorów estetycznych, zalegalizowały ją jako pożyteczne dążenie do dobrobytu"27. W tym względzie Maćko wyprzedza swoją epokę, a jego postępowanie jest zgodne z modelem szlachecko-rycerskiego życia w XVI wieku.

W skład pola znaczeniowego wartości, prócz nazw centralnych, wchodzą także dłuższe fragmenty tekstu tworzące całostki semantyczne, zawierające sugestywny opis zachowań i cech ludzkich (zwłaszcza negatywnych). Wypowiedzi te są istotne, ponieważ wprowadzają wartościowanie na zasadzie presupozycji, nie zaś arbitralnego sądu. Przykładów reprezentujących tę kategorię jest tak wiele, że nie sposób wymienić wszystkich, ograniczę się do tych najbardziej obrazowych, które opisują cechy i działania Krzyżaków. Można je podzielić na dwie główne grupy zawierające opis:

- okrucieństw i cierpień zadawanych innym ludziom, np.:

Potem znów mówili o Jurandzie, o jego nieszczęsnym losie i niewypowiedzianych krzywdach, jakich od Krzyżaków doznał, którzy naprzód bez żadnej przyczyny zamordowali mu umiłowaną żonę, a potem, zemstą płacąc za zemstę, porwali dziecko i samego umęczyli tak okrutnymi mękami, że i Tatarzy nie umieliby lepszych obmyślić. Maćko i Czech zgrzytali zębami na myśl, że nawet i w wypuszczeniu go na wolność było nowe wyrachowane okrucieństwo. (II, 162-163)

${ }^{27}$ J. Huizinga, Jesień średniowiecza, Warszawa 1998, s. 51. 
Ciężkie życie pod naszymi niemieckimi panami. Ponakładali podatki i od miewa takie, że ubogi człek musi z plewą ziarno gryźć jak bydlę. A gdzie żarna w chałupie znajda, tam chłopa skatują, dobytek zagarną, ba! dzieciom i babom nie przepuszczą... Nie boją się oni ni Boga, ni księży, jako i wielborskiego proboszcza, który im to przyganiał, na łańcuch wzięli. Oj, ciężko pod Niemcem! Co tam człek ziarna między dwoma kamieniami ugniecie, to tę przygarść mąki na świętą niedzielę chowa, a w piątek tak jeść musi jako ptacy. (I, 446)

- nierycerskich, niechrześcijańskich metod walki, np.:

Teraz jednak wydało się panu de Fourcy, że Hugo de Danveld mówi takie rzeczy i podaje takie sposoby, na które wzdrygnąć się powinna dusza w każdym rycerzu a zaś inni bracia nie tylko nie powstają na niego z gniewem, ale przytakują każdemu jego słowu. Więc zdziwienie ogarniało go coraz większe i wreszcie zadumał się głęboko, czy mu przystoi do takich uczynków rękę przykładać. (I, 352)

W przedstawionych przykładach negatywnie wartościowanych działań ujawnia się predylekcja Sienkiewicza do eksponowania i hiperbolizowania zła. Cecha ta widoczna jest zwłaszcza w wyliczeniu i nagromadzeniu w jednym miejscu wielu przykładów negatywnych zachowań Krzyżaków.

Do rejestru sposobów negatywnego oceniania, które wprowadził Sienkiewicz, zaliczyć można również liczne konstrukcje składniowe, pełniące w powieści funkcję wprost wyrażonych sądów wartościujących, np.:

- „Zakon stoi nie na prawie Bożym, ale na nieprawości i kłamstwie” (II, 366);

- „Nie ma trudniejszej rzeczy w świecie niż wydrzeć z gardła Krzyżakom raz zagrabione pieniądze" (II, 326);

- „Ziemię zagarnęli, miasta zdradą pobrali” (II, 212);

- ,wilcze oni serca mają" (II, 219);

- „podnoszą rękę na bezbronną niewiastę, na dziecko niewinne” (II, 219);

- „łapczywi są na pomstę Krzyżacy, na wykup łapczywi” (I, 450);

- „Krzyżaki po próżnicy niczego nie czynią” (I, 414);

- „Nie znają Krzyżacy bojaźni Bożej i swego dobra tylko patrzą” (I, 160);

- „Krzyżacy gotowi z Tatarami się pokumać i na nas z drugiej strony uderzyć" (I, 160);

- „Krzyżacy boją się teraz naszego narodu” (I, 159);

- „Z wilkiem ‘Krzyżakiem' nie może być zgody, bo on musi cudzym żyć” (I, 159);

- „U nich o zdradę łatwo” (I, 155);

- „Krzyżak jak może kogo zgubić, to zgubi” (I, 77);

- „A Krzyżak wtedy właśnie najzawziętszy, skoro leżącego potratuje” (I, 71); 
- „wszystko w Zakonie na ludzkich krzywdach stoi” (II, 61).

Czasami sądy te mają postać obrazowych porównań lub sentencji, np.:

- „Ich łgarstwa są jakoby bór. Z brzega jeszcze coś widać, ale im głębiej, tym większa gęstwa, że się człek zabłąka i całkiem drogę straci” (II, 60-61);

- ,jako wilcy krew naszą żłopią" (II, 196);

- „Jako tchórz cuchnie, tak Krzyżak łże” (I, 347).

Wartościowanie w świecie przedstawionym powieści przejawiało się nie tylko w zachowaniach, cechach charakteru lub nazywaniu bohaterów. Ważnym elementem służącym temu celowi był opis wyglądu zewnętrznego poszczególnych postaci reprezentujących obydwa obozy. Sienkiewicz pojmował piękno $^{28}$ jako nieodłączny element dobra, brzydota zaś zawsze towarzyszyła złu. Z tego względu w polskim obozie nie ma postaci brzydkich, o odrażającym wyglądzie ${ }^{29}$. Nawet jeśli wspomina się o jakichś defektach urody bohaterów, to zawsze w takim kontekście, który minimalizował negatywne wrażenie estetyczne. Spośród wszystkich polskich rycerzy od wzorca średniowiecznego rycerza (wysoki, muskularny, barczysty) najbardziej odbiegał wygląd Zyndrama z Maszkowic. Cechą identyfikującą tę postać były pałączaste nogi oraz zbyt długie ręce i krępa sylwetka ciała. Cechy te jednak nie przeszkadzały mu być jednym z największych wojowników i strategów swoich czasów. Sienkiewicz parokrotnie przywoływał tę postać, ale zawsze w takim ujęciu, które podkreślało inne walory rycerza, np.:

W całym Królestwie nikt tak jak on nie znał się na prowadzeniu wielkich wojsk, na szykowaniu hufców do bitwy, na budowie i burzeniu zamków, na rzucaniu mostów przez szerokie rzeki, na ,armacie”, to jest na uzbrojeniu u rozmaitych narodów, i na wszelkich wojennych sposobach. (II, 369)

Najmniej zwracał uwagi i podziwu ten, który w niedalekiej już przyszłości miał być najstraszliwszym pogromcą Zakonu, to jest Zyndram z Maszkowic, albowiem gdy zsiadł z konia, wydawał się z powodu swej niezwykłej krępości i wysokich ramion prawie garbatym. Nazbyt długie jego ręce i pałąkowate nogi budziły uśmiech w twarzach młodszych braci. Jeden z nich, znany krotofilnik, przystapił nawet do niego, chcąc mu przymówić, ale spojrzawszy w oczy pana z Maszkowic, stracił jakoś ochotę i odszedł w milczeniu. (II, 375-376)

Użycie odpowiednich środków językowo-stylistycznych, zwłaszcza w partiach narratorskich sprawia, że czytelnik przychylnie odnosi się do niedo-

${ }^{28}$ Zob. M. Pietrzak, Językowe środki kreowania postaci w twórczości historycznej Henryka Sienkiewicza, Łódź 2004, s. 63.

${ }^{29} \mathrm{Na}$ temat opisu wyglądu zewnętrznego polskich rycerzy w Krzyżakach zob. L. Mariak, Językowe wyznaczniki opisu rycerza..., s. 89-93; M. Pietrzak, op.cit. 
skonałości wyglądu polskich rycerzy. Zasada ta nie obowiązywała w kreacji negatywnego wizerunku Krzyżaków. W ich przypadku brzydota zewnętrzna była elementem dodatkowo podkreślającym czynione zło oraz negatywne cechy charakteru, np.: drapieże palce zaciskaty się kurczowo, stara, wyschta pierś z trudnościa łowiła oddech (o Zygfrydzie) (II, 73); spróchniałe zęby, grube wargi Danvelda (I, 353); wypukte oczy krzyżackiego starosty, czerwone i blyszczqce jak wilcze (I, 317); otyly, z twarza chytrego piwożtopa i grubymi, wilgotnymi wargami (o Danveldzie) (I, 313); tysiejaca nieco z tyłu płowa głowa Lichtensteina (I, 95); sępie oczy Zygfryda (II, 79). Brzydota Krzyżaków uwidaczniała się nie tylko w wyglądzie zewnętrznym, dotyczyła także ich głosu, np.: ostry głos Zygfryda do cięć miecza podobny (I, 338); syczqcy głos stużki zakonnej (I, 436); zgrzybiałość, niemoc w głosie (o Zygfrydzie) (II, 82). Nawet jeśli w opisie cech, zachowań lub wyglądu Krzyżaków pojawiały się cechy pozytywne, to zawsze w takim kontekście, który umniejszał lub całkowicie deprecjonował wcześniejsze zalety, np.:

A gorący, słynny z męstwa i okrucieństwa Rotgier mówił:

- Jak to? nie tylko dziewkę, ale i tego diabelskiego psa wypuścisz, aby znów kąsał? (II, 12)

Wolfgang, lubo niby ludzki i gladki w mowie, okazał się niepomiernie chciwym i twardym jako kamień. (II, 286)

wielki mistrz Konrad von Jungingen nie byl zlym i zepsutym czlowiekiem. [...] nie był okrutnikiem, bał się sądu Bożego [...]. Był jednakże człowiekiem słabym. (II, 364-365)

W wyniku takiej techniki obrazowania nie mamy w powieści ani jednego Krzyżaka, o którym można by powiedzieć, że jest postacią w pełni pozytywną.

Wyraźna ewaluacja pozytywna lub negatywna towarzyszy także opisowi miejsc i ziem należących do Polski (lub jej sojuszników) oraz Zakonu. Polskie krainy kojarzą się zawsze z życiem, spokojem, dobrobytem, rozkwitem, krzyżackie zaś ze śmiercią, zagładą, cierpieniem i przemocą. Dla porównania warto przytoczyć dwa, bardzo wymowne pod tym względem, fragmenty:

Ale w dalszych ziemiach samowola, srogość i rozpasanie komturów deptały prawa, szerzyły ucisk i zdzierstwa, wyciskały z pomocą nakładanych na własną rękę podatków albo i bez wszelkiego pozoru ostatni grosz, wyciskały łzy, często krew, tak że w całych obszernych krainach jeden był jęk, jedna nędza i jedna skarga. Jeśli nawet dobro Zakonu nakazywało, jak chwilami na Żmujdzi, większą łagod- 
ność - i takie nakazy szły wniwecz wobec niesforności komturów i przyrodzonego im okrucieństwa. (II, 365)

Po przebyciu puszcz, gdy weszli do „zbożnego” kraju, między osady kmiece i szlacheckie, skończyły się niebezpieczeństwa i trudy. Ludzie, dowiadując się, że to wiozą swojackie dziecko, odbite Krzyżakom, a do tego córkę sławnego Juranda, o którym „gądkowie” tyle śpiewali już pieśni po gródkach, dworzyszczach i chatach, prześcigali się w usługach i pomocy. Dostarczano zapasów i koni. Wszystkie drzwi stawały otworem. Nie potrzebował już Zbyszko wieźć Danusi w kolebce między końmi, gdyż silni młodziankowie przenosili ją w noszach ode wsi do wsi tak troskliwie i ostrożnie, jakby jakąś świętość nieśli. (II, 310-311)

Ostatnim elementem rzeczywistości powieściowej, który podlegał wartościowaniu, był świat przeżyć wewnętrznych i relacji emocjonalnych łączących bohaterów. Opisom skomplikowanych stanów uczuciowych postaci H. Sienkiewicz - realista poświęcił wiele miejsca i uwagi. Przeżycia wewnętrzne, wyrażane głównie za pomocą charakterystyki pośredniej (opis zachowań i gestów oraz wyglądu twarzy postaci), rzadko eksplicytnie ${ }^{30}$, dotyczyły zwykle uczuć najbardziej skrajnych - miłości oraz nienawiści. Podkreślić należy, że miłość i uczucia jej towarzyszące, takie jak: radość, szczęście, litość, współczucie, dotyczyły tylko postaci związanych z polskim obozem, Krzyżakom zaś były zupełnie obce. Dzięki takiej prezentacji emocji opozycja swój - obcy została jeszcze bardziej wyeksponowana. W przypadku uczucia nienawiści sytuacja nie jest już tak jednoznaczna, odczuwają ją bowiem wszyscy bohaterowie bez względu na pochodzenie społeczne, płeć czy narodowość, których losy wiązały się z burzliwym konfliktem polsko-krzyżackim. Pomimo iż samo uczucie nienawiści było wspólne dla obu stron, to jednak różne towarzyszyły mu motywy: źródłem nienawiści i niechęci Polaków były krzywdy doznane od Zakonu, u Krzyżaków zaś wrogość wynikała z poczucia wyższości rasowej i przyrodzonego zła:

Ludzie ci prosili, by im pozwolono wziąć udział w wojnie „na piechtę” - albowiem chcieli pomścić się swych krzywd na Krzyżakach, których nienawidzili duszą całą. (II, 468)

Nienawidzą w całych Prusiech Krzyżaków i księża, i szlachta, i mieszczanie, i kmiecie. I nienawidzi ich nie tylko ten naród, któren naszą alibo pruską mową mówi, ale nawet i Niemcy... (II, 391-392)

${ }^{30}$ Zob. M. Pietrzak, op.cit. 
A teraz ów synaczek rozleje raz jeszcze znienawidzoną krew polską i wróci okryty chwała. (II, 74)

Zygfryd de Löwe zawahał się przez chwilę z odpowiedzią; w naturze jego leżała głęboka nienawiść do polskiego plemienia, leżało okrucieństwo, którym nawet Danvelda przewyższał. (II, 23-24)

Dla uwydatnienia skali odczuwanej nienawiści posłużył się H. Sienkiewicz obrazowymi porównaniami, które dzięki swej plastyczności trafiały do wyobraźni czytelnika:

bo $i$ to wiem, że nienawidzi on [Jagiełło - L.M.] jak trądu Krzyżaków. (II, 428)

Wiek życia zbiegł mu w polu przeciw Tatarom, z którymi długie lata walczył na Rusi, i przeciw Niemcom, których nienawidzil jak zarazy. (II, 201)

Komparans tych porównań zawierający odwołania do realiów średniowiecznych ewokujących asocjacje z najgorszymi plagami tych czasów: zarazą i trądem doskonale oddawał skalę nienawiści, jaką wtedy Polacy czuli wobec Krzyżaków.

Rzeczywistość wykreowaną w powieści charakteryzuje wyraźne nacechowanie aksjologiczne. Świat pozytywnych wartości polskich (słowiańskich) różni się zasadniczo od świata negatywnych wartości krzyżackich (niemieckich, germańskich). Ten czarno-biały manichejski obraz ukształtowany na bazie wspólnoty doświadczeń i przeżyć dzięki swej jednoznaczności, stereotypowości miał się utrwalić w pamięci czytelników, wywołać odpowiednie emocje, a przede wszystkim utwierdzić w przekonaniu o wyższości naszej kultury, naszego świata, wobec kultury, postaw świata niemieckiego. Spośród wszystkich kategorii wartości najbardziej wyeksponowane zostały wartości moralne oraz pragmatyczne. W zakresie nazw wartości i w ogóle słownictwa nacechowanego aksjologicznie dominują określenia nacechowane negatywnie. Na płaszczyźnie językowej zastosowane przez H. Sienkiewicza sposoby formułowania ocen, propagowania pożądanych wartości i ganienia negatywnych były różne. Do najczęściej używanych zaliczyć można: nazwy synonimiczne przedstawicieli przeciwnych obozów, przymiotniki wartościujące, przekształcenia 
semantyczne, a także większe całostki tekstu o odpowiednim znaczeniu. Wartościowanie objęło przede wszystkim czyny, wypowiedzi, a także cechy wyglądu zewnętrznego oraz uczucia bohaterów. Rzadziej ocenie podlegały inne elementy świata przedstawionego, np. miejsca, rzeczy. W procesie wyrażania wartości H. Sienkiewicz wykorzystał słownictwo ogólnie oceniające, np.: dobry, zły, opisowo-oceniające, np.: kat, kłamstwo, prawda oraz odpowiednio dobrany kontekst. Można zatem mówić o dwóch typach ocen: bezpośrednich, wyrażonych za pomocą na przykład nazw synonimicznych, przymiotników wartościujących oraz pośrednich wynikających z przekształceń semantycznych, kontekstu, presupozycji. Manichejska wizja świata wprowadzona do powieści sprawiła, że z realiami polskimi łączone było tylko to, co dobre, pożyteczne, piękne i służące ludziom. Świat wartości niemieckich, obcych kojarzył się z wszechobecnym złem, krzywdą ludzką i brzydotą.

Na zakończenie warto zastanowić się, czy taki jednoznacznie zaksjologizowany sposób prezentacji rzeczywistości literackiej nie był manipulacją i czy na przykład H. Sienkiewicz nie przesadził w negatywnym wartościowaniu realiów krzyżacko-niemieckich. Zdaniem Stefana Kuczyńskiego, badacza rzeczywistości historycznej w Krzyżakach, obraz ten nie tylko nie jest przejaskrawiony, ale ,przeciwnie, posiada jeszcze zbyt delikatne barwy" ${ }^{31}$. $\mathrm{Na}$ potwierdzenie swej tezy autor wymienia kilkadziesiąt różnych, poświadczonych przez źródła historyczne, faktów dokumentujących zdrady, nieprawości i przestępstwa popełnione przez Zakon w tych czasach ${ }^{32}$.

\section{Leonarda Mariak}

\section{The World of Domestic and Foreign Values in the Novel Krzyzacy (“Teutonic Knights”) by Henryk Sienkiewicz}

The article discusses the linguistic devices of the evaluation of the characters created in the realities of the novel (fictitious and historical) connected with two opposite groups: the Poles (domestic) and the Teutonic Knights (foreign). The analysis of the material has revealed the persuasive mechanisms applied by Henryk Sienkiewicz in order to exert influence on the readers' attitudes and their system of values. The repertoire of linguistic and semantic devices used for evaluation is very diversified and, among others, includes: synonymic passages giving names to the representatives of both groups, the names of values (positive or negative) and the phrases describing actions, character features and people's attitudes evaluated as positive or negative, connecting synonymous names (of Poles and the Teutonic Knights) with different parts of

\footnotetext{
31 S. Kuczyński, op.cit., s. 130.

32 Ibidem, s. 130-133.
} 
speech; statements with specific connotations (positive or negative) informing about the actions, behaviours and appearance of the characters; stylistic means such as: similes, metaphors, epithets used in an expressive and evaluating function.

Additionally, the conclusions drawn from the research shed light on Henryk Sienkiewicz's writing techniques. It has become feasible to reconstruct (indirectly) the writer's attitudes towards life and the system of values. 